\title{
Phytochemical Determination and Antibacterial Activity of Urtica dioica Leave Extracts against Isolated Food Borne Bacteria
}

\author{
Geeta Rawat $^{1 *}$ and Alka Bameta ${ }^{2}$ \\ ${ }^{1}$ Sardar Bhagwan Singh University, Dehradun, India \\ ${ }^{2}$ Govind Ballabh Pant University of Agriculture and Technology, Pantnagar, India \\ *Corresponding author
}

\begin{tabular}{l} 
Ke y w o r d s \\
Antibacterial \\
activity, Bacteria, \\
$\begin{array}{l}\text { Food-borne, } \\
\text { Inhibitory zone, } \\
\text { Phytochemical }\end{array}$ \\
\hline Article Info \\
\hline $\begin{array}{l}\text { Accepted: } \\
15 \text { November } 2019 \\
\text { Available Online: } \\
10 \text { December } 2019\end{array}$ \\
\hline
\end{tabular}

\section{A B S T R A C T}

Aim of this study was to analyze phytochemical constituents and antibacterial activity of Urtica dioica leave extracts against isolated foodborne pathogens from different food samples. The phytochemical analysis showed the presence of carbohydrates, alkaloids, saponins, tannins and protein. Total 75 different isolates of bacteria were isolated from different food samples. Out of 75twenty-four were found to be positive for Klebsiella, twenty-six for Staphylococcus spp. and twenty-five for E. coli. Maximum zone of inhibition was recorded by ethyl acetate extract against E. coli with $2.36 \pm 0.26 \mathrm{~mm}$ diameter followed by Klebsiella $(2.28 \pm 0.16$ $\mathrm{mm})$ Staphylococcus spp. $(1.96 \pm 0.28 \mathrm{~mm})$ respectively. Methanol extract showed maximum inhibitory zone of $1.91 \pm 0.26 \mathrm{~mm}$ against Klebsiella followed by $1.82 \pm 0.33 \mathrm{~mm}$ zone against Staphylococcus spp. and $1.5 \pm 0.17$ $\mathrm{mm}$ inhibitory zone against $E$. coli. Aqueous extract not showed inhibition against any isolated bacteria.

\section{Introduction}

Current national and international trends in antibiotic resistance are becoming a public health crisis. Multidrug resistant organisms are most prevalent in hospital setting and alarmingly are now being identified in the community. Prevalence of several microorganisms in different food samples are responsible for different food-borne diseases.
Many times these diseases are fatal and lead to a hazardous condition.

Urtica dioica (family Urticaceaeis) is a high value medicinal plant, recommended for treating osteoarthritis and urinary tract infections, rheumatoid arthritis, Alzheimer's disease, allergies, asthma, bronchitis, bursitis, cough, gout, gingivitis, hair growth and baldness, prostate enlargement, sciatica, 
tendinitis, kidney stones (Banso and Adeyemo 2006, Bandow,et al., 2003). New antimicrobial agents are required to treat human and animal diseases caused by drug resistant microorganisms. Interest has been increasing in plant-derived drugs, mainly due to the belief that "green medicine" is harmless and more reliable than costly manmade drugs (Belyakova et al., 2002; Benkeblia, 2004). Urtica dioica is stated to possess antihaemorrhagic and hypoglycemic properties.

Natural products provide boundless prospects for new drug leads because of the availability of chemical diversity. There is a continuous and urgent need to discover new antimicrobial compounds with varied chemical structures and new mechanisms of action for new infectious diseases (Cowan, 1999). Hence, researchers are progressively turning their consideration to traditional medicine, looking for novel leads to develop improved drugs against microbial infections (Benkeblia, 2004; Banso and Adeyemo, 2006; Bandow et al., 2003; De Boer et al., 2005). So the main objective of the present study is to investigate the phytochemical constituents in Urtica dioica leave extracts and their antibacterial effect on isolated food-borne bacteria.

\section{Materials and Methods}

\section{Sample collection}

The samples including leaves of Urtica dioica were collected from local area around Dehradun (Uttarakhand) during February.

\section{Methanolic and ethyl acetate extract preparation}

The plant materials were collected, washed and dried for few days in a shade at ambient temperature $\left(31^{\circ} \mathrm{C}\right)$. Dried plant leaves were crushed by a laboratory blender and weighed before extraction. Organic solvent extraction of nettle was carried out by using ethanol (95\%) and ethyl acetate (95\%) which is considered as very effective in extracting the active ingredients of the plant according to method described by Ilhami et al., (2004) and Inouye et al., (2001). This was done by using Soxhlet assembly, which consists of a heating element, which is used for heating the solvent taken in a round bottom glass flask that fitted to an extraction chamber. The extracting unit contains the solvent and cellulose (thimble) located inside it that contains the dry plant powder. A bulb type condenser is fitted on to the extraction unit. The soxhlets extractor acts on the principle of continuous heat percolation process. Small volume of hot solvent is passed through the material filled in the cylinder a number of times till active constituents of the material get exhausted. For condensation of vapor solvents, $20 \mathrm{gm}$. of powdered plant material (leaves) powder was taken in the thimble and $200 \mathrm{ml}$ solvents (i.e. methanol ethyl, acetate) were placed inside the flask. The extraction was carried out for 8 to 10 hours by heating temperature that kept the solvent at $70{ }^{\circ} \mathrm{C}$ (methanol) and $75 \circ \mathrm{C}$ (ethyl acetate). After that, the extract was dried by using an electric oven at temperature $40-45{ }^{\circ} \mathrm{C}$ until dry extract was obtained. The dry extract was placed in an incubator under $38-40{ }^{\circ} \mathrm{C}$ for complete dryness of the sample. The dried extracts are dissolved in Dimethyl sulphoxide (DMSO) to prepare concentration of 100 $\mathrm{mg} / \mathrm{mL}$ that is used for testing its antibacterial activity.

\section{Aqueous extraction}

Plant leaves were washed under tap water and then shade-dried in room temperature. The plant material was chopped into small pieces and then grinded by an electric blender into powder. The powdered mixture $(50 \mathrm{gm}$.) was mixed with $100 \mathrm{ml}$ distilled water. Aqueous extract was carried out according to Inouye $e t$ 
al., (2001) Joanne et al., (2002) by using magnetic stirrer at $60{ }^{\circ} \mathrm{C}$ for 3 hours, then filtrate was kept in incubator till complete drying. The yield of dry powder was $15 \mathrm{gm}$.

The dry powder was dissolved in DMSO to prepare concentration of $100 \mathrm{mg} / \mathrm{mL}$ that was used for testing antibacterial activity.

Phytochemical screening (Brinda and Sarswatih, 1981)

All the extracts (methanol, ethyl acetate and aqueous) were individually subjected to qualitative analysis of the active compounds present in them. The compounds screened are carbohydrate, alkaloids, saponins, flavonoids, tannins and proteins.

\section{Test for flavonoids}

Few drops of extract were taken in test tube to which 3-4 drops of $\mathrm{FeCl}_{3}$ was added. The green color indicated the presence of phenolics in the sample.

\section{Test for alkaloids}

$1 \mathrm{~mL}$ of Wagner's reagent was added to $1 \mathrm{~mL}$ of extract. Brown precipitate indicated the presence of alkaloids.

\section{Test for saponins}

To $1 \mathrm{ml}$ of extract was added $2 \mathrm{~mL}$ of distilled water in graded cylinder and then shaken vigorously for 15 mins. A $1 \mathrm{~cm}$ layer of foam indicates the presence of saponins.

\section{Test for tannins}

$1 \mathrm{ml}$ of extract was taken separately in few $\mathrm{ml}$ of alcohol. To this few drops of freshly prepared $\mathrm{FeCl}_{3}$ was added. Development of greenish violet colour indicated the presence of tannins.

\section{Carbohydrates}

To $1 \mathrm{ml}$ of Fehling's reagent was added to $1 \mathrm{ml}$ of water in a test tube, mixed thoroughly and kept in water bath. The formation of red precipitate (cuprous oxide) in the bottom of the tube indicates the presence of carbohydrates.

\section{Proteins}

Add $1 \mathrm{~mL}$ of concentrated $\mathrm{HNO}_{3}$ to $2 \mathrm{~mL}$ extract. A white precipitate formed. Boiled the solution and colour changes to yellow. Cool the test tube and $2 \mathrm{~mL}$ of $20 \% \mathrm{NaOH}$ to make it alkaline. The colour changes to orange indicated the presence of proteins.

\section{Food Sample collection}

Food samples (cooked) were collected from local market, Dehradun (India) in sterile plastic bags and further used for microbial analysis.

\section{Isolation of food borne pathogens}

The samples are rinsed thoroughly with distilled water and used for isolation of bacteria on specific media nutrient agar and MacConkey agar. For cultivation of Klebsiella the sample rinsate was inoculated into Mac Conkey agar at $37^{\circ} \mathrm{C}$ for 24 hours. For the isolation of Staphylococcus spp. and E. coli, the rinsate was incubated into nutrient agar media at $37^{\circ} \mathrm{C}$ for 24 hours.

\section{Morphological and biochemical characterization}

Characterization of the colony isolates was achieved by initial morphological examination of the colonies in the plate for colonial appearance, size form, elevation, color and pigmentation and the results were recorded. Biochemical characterization of bacteria was done by performing specific tests such as 
indole, Methyl Red, Voges Proskauer, citrate, glucose, sucrose and urease test.

Determination of Antimicrobial ActivityDisc diffusion method (Maruzzella and Henry, 1958)

Nutrient Agar (NA) plates were seeded with 8 $\mathrm{h}$ broth culture of different bacteria. The disc was made up of Whatman no 1 filter paper having diameter of $6 \mathrm{~mm}$. The discs were sterilized before use. $20 \mathrm{uL}$ of different extract solution (ethyl acetate, methanol and aqueous) were taken in the disc with the help of micropipette and forceps. Discs injected with $20 \mathrm{uL}$ of DMSO served as control. The discs were injected with extracts were placed on solid agar medium by pressing gently. The bacterial plates were incubated at $37^{\circ} \mathrm{C}$ for 24 hrs. The antimicrobial activity was evaluated by measuring the diameter of inhibition zone with the help of the ruler. The experiment was carried out in triplicate and the mean of the diameter of the inhibition zones was calculated.

\section{Statistical analysis}

Three replicates of each sample were taken and experiments were repeated thrice. The statistical analysis was done by ANOVA and significance of differences between replicates were measured at $5 \%(\mathrm{P}<0.05)$.

\section{Results and Discussion}

\section{Qualitative Phytochemical Analysis}

The presence of different compounds in extracts of Urtica dioica was determined by qualitative phytochemical analysis. The results of the phytochemical analysis are presented in Table 1. Leaf ethyl acetate possess only alkaloids and flavonoids. Carbohydrates saponins, tannins and proteins were absent in ethyl acetate extract. Carbohydrates, alkaloids, flavonoids and tannins were detected in the methanol leaf extract. Saponins and proteins were absent in leaf methanol extract. In aqueous leaf extract carbohydrates, alkaloids, saponins and flavonoids were present while tannins and proteins absent. Nettle has different constituents (i.e. alkaloids, phenols, flavonoids, tannins and saponins) which plays major role in antibacterial antimicrobial activity (Cowan, 1999; Le Grand et al., 1988). Alkaloid, it is antibacterial activity may be due to its ability to react with carboxyl, amino, hydroxyl and sulfhydryl groups in bacterial nucleic acid as well as protein, it very reactive chemical compounds that associated with proteins to give intermolecular cross-links and intercalate with DNA (Onmetta-aree, 2005). Tannin is the another constituent which are precipitate gelatin from solution, a property is known as astringency. It has been reported to inhibit the development of microorganisms by precipitating microbial protein and making nutritional proteins unavailable for them (Gonzalez-Lamothe et al., 2009; Palic et al., 2002). Phenolic compound is mostly hydrophobic in nature which has a hydroxyl group (-OH). The antimicrobial activity due to this group is well known, the number and site(s) of -OH groups on the phenol group are thought to be related to their relative activity to microorganisms (Randall et al., 2000; Rojas et al., 2003). Abdeltawab et al., (2012) also reported that Urtica dioica is a rich source of phytochemicals such as phenolic compounds and minerals which can be used as a potential source of useful drugs. Bameta et al., (2017) documented the presence of phenol, steroids, saponins, tannins coumarin and reducing sugar in Nerium oleander.

\section{Isolation of food born microorganisms}

Out of total 33 samples, 75 total different isolates of bacteria were isolated from food samples. In that 25 were found to be positive for $E$. coli, 24 were found to be positive for Klebsiella and 26 were found to be positive for Staphylococcus spp. (Table 2). All the 
samples were streaked on the surface of Mac Conkey agar as well as on the surface of nutrient agar for the growth after overnight incubation.

\section{Morphological and biochemical characterization of different bacterial isolates}

E. coli is seen as a gram negative, rod shaped, motile, flagellated bacteria (Figure 1a). The microscopic appearance of Staphylococcus spp. was of gram-positive cocci. The organism appears purple (Figure 1b). Klebsiella is seen as a non motile, Gram negative, bacteria (Figure 1c).

Klebsiella isolates grew in Mac Conkey were found to be Mucoid pink (Figure 1d). All the E. coli isolates grew on nutrient agar producing white colonies (Figure 1e) while Staphylococcus spp. producing golden yellow colonies (Figure 1e). Isolates belongs to $E$. coli were Indole, Methyl Red positive as shown by change in colour however, Voges Proskauer was negative for all the isolates.

They fermented glucose and sucrose with the production of acid gas. They were negative for other biochemical tests performed such as urease production and citrate utilization. Staphylococcus spp. isolates were found to be Methyl Red, Voges Proskauer, citrate, glucose, sucrose and urease test positive negative for indole test. All the isolates grew on Mac Conkey agar medium producing colonies of pink or light pink color. All the isolates belonging to Klebsiella were positive for Voges Proskauer, citrate utilization and urease production however, they were negative for indole and methyl red test as there was no change in color. Like E. coli they fermented glucose and sucrose with the production of acid gas (Table 3 ).

Table.1 Qualitative phytochemical analysis of Urtica dioica extracts

\begin{tabular}{|c|c|c|c|c|}
\hline S. No. & Tests performed & Ethyl acetate & Methanol & Aqueous \\
\hline $\mathbf{1}$ & carbohydrates & - & + & + \\
\hline $\mathbf{2}$ & Alkaloids & + & + & + \\
\hline $\mathbf{3}$ & Saponins & - & - & + \\
\hline $\mathbf{4}$ & Flavonoids & + & + & + \\
\hline $\mathbf{5}$ & Tannin & - & + & - \\
\hline $\mathbf{6}$ & Proteins & - & - & - \\
\hline
\end{tabular}

Table.2 Number of isolates in food samples

\begin{tabular}{|c|c|c|c|c|c|c|}
\hline S.No. & Samples & $\begin{array}{c}\text { Total no of } \\
\text { samples }\end{array}$ & $\begin{array}{c}\text { Total no of } \\
\text { isolates }\end{array}$ & $\begin{array}{c}\text { Total } \\
\text { number of } \\
\text { E. coli } \\
\text { isolates }\end{array}$ & $\begin{array}{c}\text { Total number } \\
\text { of Klebsiella } \\
\text { isolates }\end{array}$ & $\begin{array}{c}\text { Total number of } \\
\text { Staphylococcus } \\
\text { spp. } \text { isolates }\end{array}$ \\
\hline $\mathbf{1}$ & Spoiled rice & 04 & 22 & 09 & 06 & 07 \\
\hline $\mathbf{2}$ & Spoiled daal & 13 & 18 & 04 & 08 & 06 \\
\hline $\mathbf{3}$ & Spoiled vegetables & 16 & 35 & 12 & 10 & 13 \\
\hline & $\begin{array}{c}\text { Total no of } \\
\text { samples }= \\
33\end{array}$ & $\begin{array}{c}\text { Total no of } \\
\text { isolates }=75\end{array}$ & $\begin{array}{c}\text { Total } \\
\text { number of } \\
\text { E. coli } \\
\text { isolates=25 }\end{array}$ & $\begin{array}{c}\text { Total number } \\
\text { of Klebsiella } \\
\text { isolates=24 }\end{array}$ & $\begin{array}{c}\text { Total number of } \\
\text { Staphylococcus spp. } \\
\text { isolates }=26\end{array}$ \\
\hline
\end{tabular}


Table.3 Culture and biochemical characteristics of different isolates

\begin{tabular}{|c|c|c|c|c|}
\hline $\begin{array}{c}\text { S. } \\
\text { No. }\end{array}$ & Characteristics & \multicolumn{3}{|c|}{ Organisms } \\
\hline & & E. coli & Klebsiella & Staphylococcus spp \\
\hline $\mathbf{1}$ & $\begin{array}{c}\text { Culture } \\
\text { characteristics }\end{array}$ & $\begin{array}{c}\text { White colour } \\
\text { colonies }\end{array}$ & $\begin{array}{c}\text { Mucoid pink colour } \\
\text { colonies }\end{array}$ & $\begin{array}{c}\text { Golden yellow } \\
\text { colonies }\end{array}$ \\
\hline $\mathbf{2}$ & $\begin{array}{c}\text { Biochemical } \\
\text { characteristics }\end{array}$ & & & - \\
\hline & Indole & + & - & + \\
\hline & Methyl Red & + & - & + \\
\hline & Voges Proskauer & - & + & + \\
\hline & Citrate & - & + & + \\
\hline & Glucose & + & + & + \\
\hline
\end{tabular}

Fig.1 (a) E. coli (b) Staphylococcus spp. (c) Klebsiella (d) Mac Conkey plates with lactose fermenting colonies (Klebsiella) (e1) Nutrient agar plate having Staphylococcus spp. (e2)

Nutrient agar plate having $E$. coli
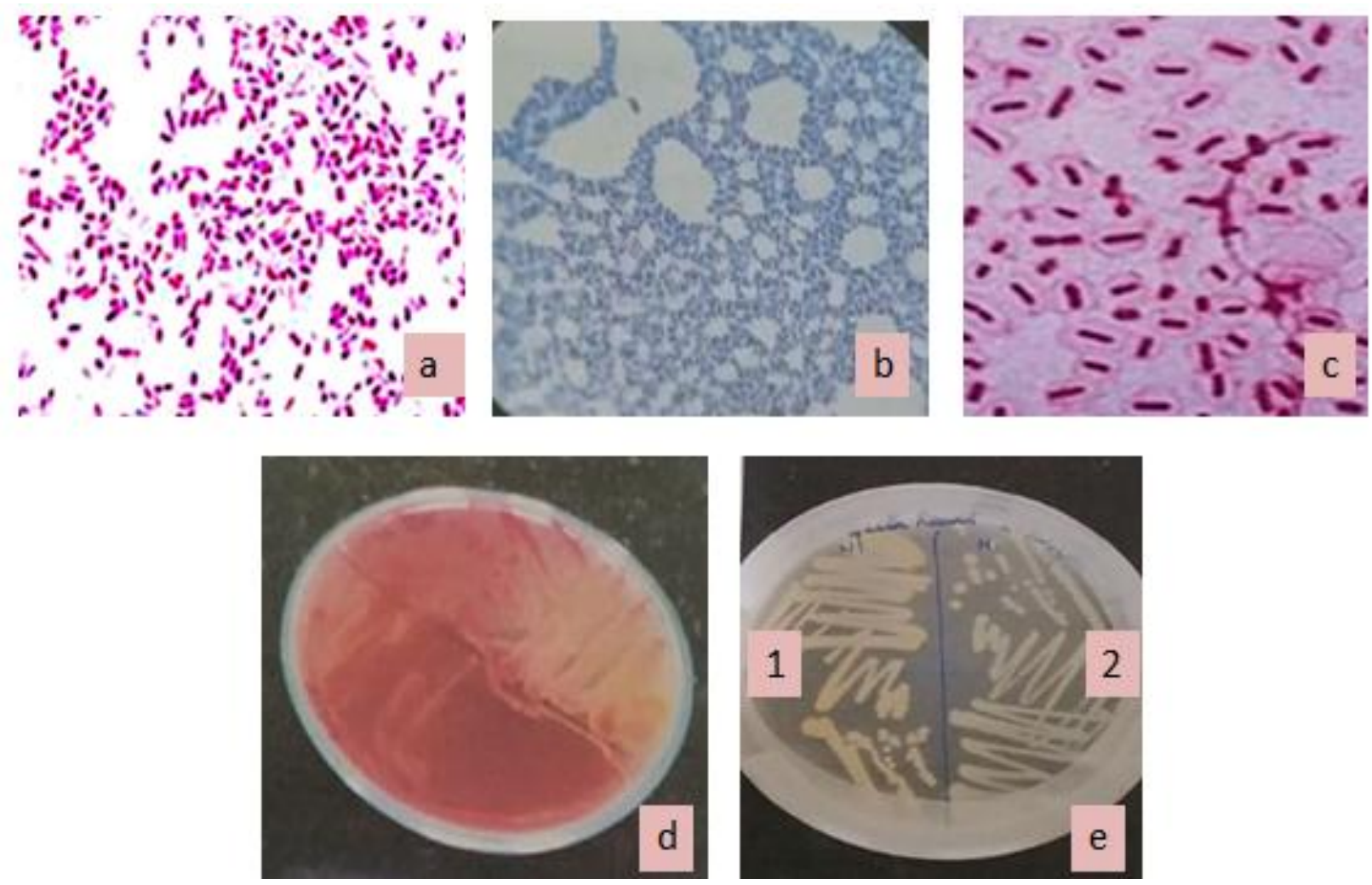
Table.4 Antibacterial effect of ethyl acetate, methonolic and aqueous extract of Urtica dioica against some bacterial isolate

\begin{tabular}{|c|c|c|c|c|}
\hline \multirow{2}{*}{ S.No. } & \multirow{2}{*}{ Isolates } & \multicolumn{3}{|c|}{ Diameter of inhibition zone(mm) } \\
\cline { 3 - 5 } & & $\begin{array}{c}\text { Ethyl acetate } \\
(\mathbf{1 0 0} \mathbf{~ m g} / \mathbf{m L})\end{array}$ & $\begin{array}{c}\text { Methanol extract } \\
(\mathbf{1 0 0} \mathbf{~ m g} / \mathbf{m L})\end{array}$ & $\begin{array}{c}\text { Aqueous extract } \\
(\mathbf{1 0 0} \mathbf{~ m g} / \mathbf{m L})\end{array}$ \\
\hline $\mathbf{1}$ & E. coli & $2.36 \pm 0.26$ & $1.5 \pm 0.17$ & $0.0 \pm 0.0$ \\
\hline $\mathbf{2}$ & Klebsiella & $2.28 \pm 0.16$ & $1.91 \pm 0.26$ & $0.0 \pm 0.0$ \\
\hline $\mathbf{3}$ & Staphylococcus spp. & $1.96 \pm 0.28$ & $1.82 \pm 0.33$ & $0.0 \pm 0.0$ \\
\hline
\end{tabular}

Fig.2 Antibacterial activity of leaf extract

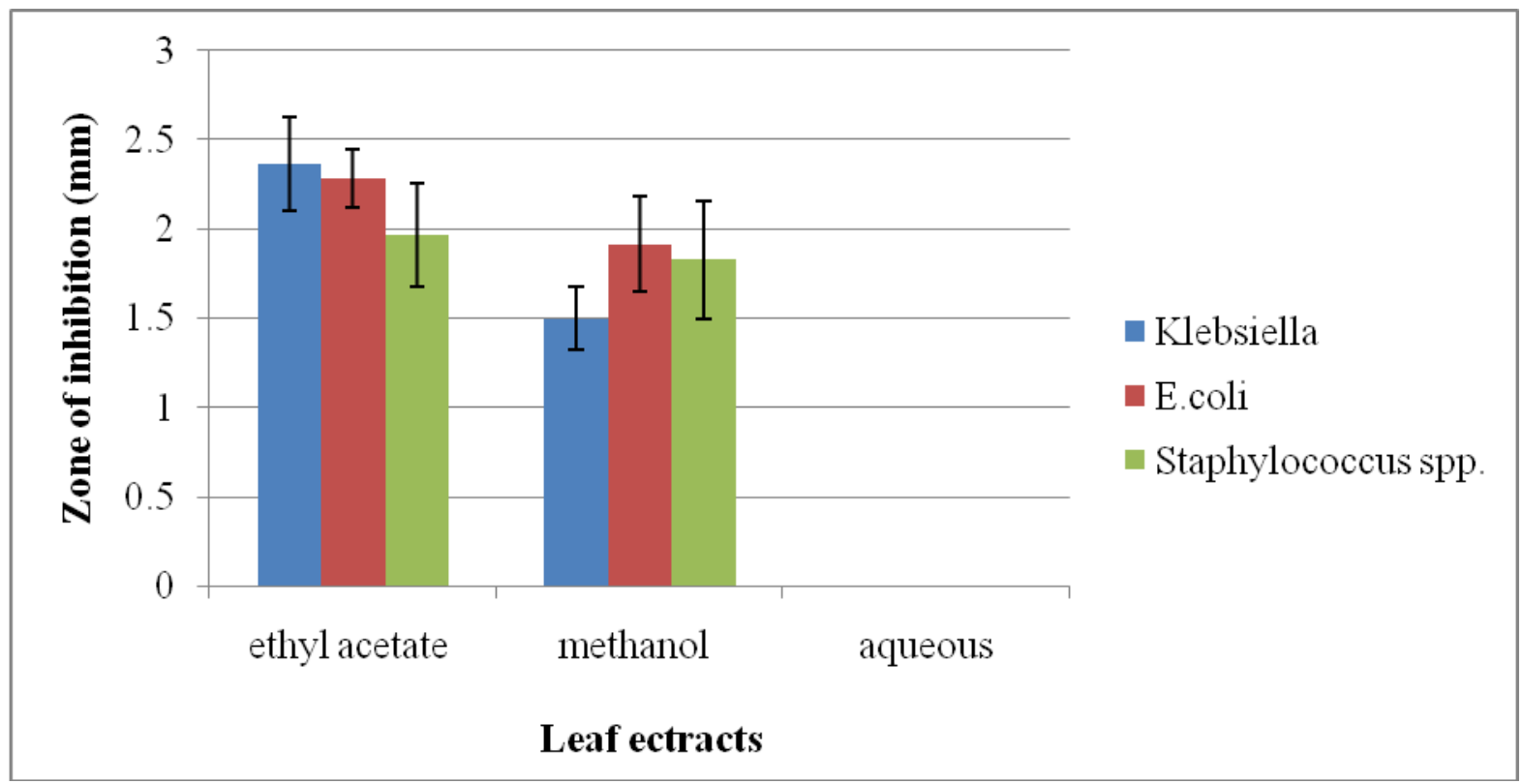

Antibacterial activity of different extracts against different isolated food born bacteria

On comparing the antimicrobial activity of ethyl acetate, methanol and aqueous extracts, results shows that ethyl acetate extract has maximum antimicrobial activity against $E$. coli (2.36 \pm 0.26$)$ followed by Klebsiella (2.28 \pm 0.16$)$ Staphylococcus spp. $(1.96 \pm 0.28)$ respectively. Methanolic extract showed antibacterial activity against all bacterial isolates. Maximum zone of inhibition was displayed by Klebsiella $(1.91 \pm 0.26)$ followed by Staphylococcus spp. $(1.82 \pm 0.33)$ and E.coli $(1.5 \pm 0.17)$. Aqueous extract was showed negative result against all bacterial strains (Table 4 and Figure 2).
The antibacterial activity of $95 \%$ ethanol and aqueous extracts of nettle leaf were tested against $S$. aureus, E. coli, Klebsiella spp., $B$. subtillus, Proteus spp. Salmonella spp. and Pseudomonas spp. (Salih et al., 2014). S. aureus, B. subtillus and Salmonella spp. showed the highest susceptibility to Urtica dioica extracts antibacterial effect, while Pseudomonas, E coli and Proteus were less susceptible. Animal studies proved that nettle leaf extract may inhibit blood clotting, can decrease total cholesterol levels as well as enhance the overall liver function (EI Haouari et al., 2006; Nassiri et al., 2009).

Terpenes and phenols of $U$. dioca are one of the major groups associated with the inhibition 
of microbial inhibitions and cancer (Dar et al., 2012). The results of Chahardehi et al., (2012) revealed that ethyl acetate, hexane and chloroform extracts showed highest inhibition against B. cereus, Staphylococcus aureus and Vibrio parahaemolyticus. The ethanol extract of nettle leaves did not inhibit the growth of $E$. coli ATCC 9837 (Sanchez, et al., 2009), unlike the water extract, which exhibit considerable antibacterial activity (Gulcin et al., 2004).

\section{References}

Abdeltawab, A. A., Ullah, Z., Al-Othman, A. M., Ullah, R., Hussain, I., Ahmad, S., \& Talha, M. 2012. Evaluation of the chemical composition and element analysis of Urtica dioca. African Journal of Pharmacy and Pharmacology, 6(21): 1555-1558.

Bameta, A., Kumari, A., and Upadhyaya, A. 2017. Phytochemical analysis and antimicrobial activity of Nerium oleander L., International Journal of Biology Research 2(3): 29-32.

Bandow, J.E., Brotz, H., and Leichert, L.2003. Proteomic approach to understanding antibiotic action. Antimicrob Agents Chemother 47: 948-955.

Banso, A. and Adeyemo, S. 2006. Phytochemical screening and antimicrobial assessment of Abutilon mauritianum, Bacopamonnifera and Daturastramonium. Biokemistri, 18(1): 39-44.

Belyakova, V. A., Vainshtein, K. V., Markova, Yu. T., Demchenko and T. H. Chibilyaev 2002. Extraction of nettle leaves using synthetic esters of fatty acids. Pharmaceutical Chemistry Journal, 39(11): 598-602.

Benkeblia N. 2004. Antimicrobial activity of essential oil extracts of various onions (Allium cepa) and garlic (Allium sativum). Lebensm-Wiss u-Technol 37: 263268,

Brindha, P. and Saraswathy, A.1981. Phytochemical comparison of Pentatropis, Oldenlandia and plumeria. In: Proc. Natl. Seminar on Recent Trends in Natural
Products Chemistry, held on March 30-31, at Bharathidasan Univ., Tiruchirappalli, India.

Cowan, M. 1999. Plant products asantimicrobial agents. Clinical Microbiology Reviews. 12(4): 564-582.

Dar, S. A., Yousuf, A. R., Ganai, F. A., Sharma, P., Kumar, N., and Singh, R. 2012. Bioassay guided isolation and identification of anti-inflammatory and anti-microbial compounds from Urtica dioica L. (Urticaceae) leaves. African Journal of Biotechnology, 11(65): 1291012920.

De Boer HJ, Kool A, Broberg A. Antifungal and antibacterial activity of some herbal remedies from Tanzania. J Ethnopharmacol 96: 461-469, 2005.

El Haouari, M., Bnouham, M., Bendahou, M., Aziz, M., Ziyyat, A., Legssyer, A., and Mekhfi, H. 2006. Inhibition of rat platelet aggregation by Urtica dioica leaves extracts. Phytotherapy Research: An International Journal Devoted to Pharmacological and Toxicological Evaluation of Natural Product Derivatives, 20(7): 568-572.

Gonzalez-Lamothe, R., Gabriel Mitchell, G., Mariza Gattuso, M., Moussa S., Diarra, T., Malouin, F. and Kamal Bouarab, K. 2009. Plant antimicrobial agents and their effects on plant and human pathogens. J. Mol. Sci., 10: 3400-3419.

Gulcin, I, Kufrevioglu, O.I, Oktay, M, Buyukokuroglu, M.E. 2004 Antioxidant, antimicrobial, antiulcer and analgesic activities of nettle (Urtica dioica L.). Journal of Ethnopharmacology, 90: 205215.

Ilhami, G.O., Irfan, K. G., Münir O. and Mehmet Emin, B.G. 2004. Antioxidant, antimicrobial, antiulcer and analgesic activities of nettle (Urtica dioica L.). Journal of Ethnopharmacology 90: 205215.

Inouye, S., Takizawa, T. and Yamaguchi, M. 2001. Antimicrobial activity of essential oil and their major constituents against respiratory tract pathogens by gaseous 
contact. Journal of antimicrobial chemotherapy, 47: 565573.

Joanne B., Linda. A and. Philipson J. D. 2002.Herbal medicines. (Second edition), published by pharmaceutical press (publication division of the Royal pharmaceutical society of Great Britain 269-276

Le Grand A., Wondergem P.A., Verpoorte R., Pousset J.L. 1988. Anti-infectious phytotherapies of the tree Savannah of Senegal (West-Africa) II. Antimicrobial activity of 33 species. J. of Ethanopharmacol, 22(1): 25-31.

Maruzella, J.C. and Henry, P.A. 1958. The antimicrobial activity of perfume oils. $J$. Am. Pharma. Asso.28: 471.

Modarresi-Chahardehi, A., Ibrahim, D., FarizaSulaiman, S., and Mousavi, L. 2012. Screening antimicrobial activity of various extracts of Urtica dioica. Revista de biologia tropical, 60(4): 1567-1576.

Namazi, N., Esfanjani, A. T., Heshmati, J., Bahrami, A., and Nazemiyeh, H. 2012. A systematic review about effects of aerial portions of Urtica dioica (nettle) on some cardiovascular risk factors in diabetes mellitus. Int J Pharm, 8: 306-313.

Onmetta-aree, J. 2005. Effects of the Zingiberaceae spice extracts on growth and morphological changes of food borne pathogens. Ph.D. Thesis Submitted in Partial Fulfillment of the Requirements for the Degree of Doctor of Philosophy in Food Technology Suranaree University of
Technology Academic Year. Zingibar. Tanzania.

Palic, R., G. Stojanovic, S. Alagic, M. Nikolic and Z. Lepojevic. 2002. Chemical composition and antimicrobial activity of the essential oil and $\mathrm{CO} 2$ extracts of the oriental tobacco, Prilep. FlavourFragr. J., 17: 323-326.

Randall, C., Randall, H., Dobbs, F., Hutton, C., and Sanders, H. 2000. Randomized controlled trial of nettle sting for treatment of base-of-thumb pain. J R Soc Med, 93: 305-309.

Rojas, R., Bustamante, B., Bauer, J., Fernandez, I., Alban, J., and Lock, O. 2003. Antimicrobial activity of selected Peruvian medicinal plants. J Ethnopharmacol 88: 199- 204,

Sanchez, D.O.S., Najera, G.L.A., Rivera, I.L., Ramirez, O.D., Cisneros, Ma. G.V., Garcia, V.M.N. 2009. Antimicrobial Activity of Medicinal Plants from the Huautla Sierra Biosphere Reserve in Morelos (Maxicon). Polibotanica, 28:213225.

Semra, I., Filiz, S., and Ferdag, C. 2007. Antibacterial and antifungal activity of Corchorus olitorius L. Molokhia) extracts. Inter J Natural Engineering Sci, 1: 59-61.

Sharon, N. and Ofec, I. 1986. Mannose specific bacterial surface lectins. In:D.Mirelman (ed), Microbial lectins and agglutinins: properties and biological activity, John Wiley and Sons, Inc. New York, 55-81.

\section{How to cite this article:}

Geeta Rawat and Alka Bameta. 2019. Phytochemical Determination and Antibacterial Activity of Urtica dioica Leave Extracts against Isolated Food Borne Bacteria. Int.J.Curr.Microbiol.App.Sci. 8(12): 1704-1712. doi: https://doi.org/10.20546/ijcmas.2019.812.205 